\title{
Analyzing the Reading Skills and Visual Perception Levels of First Grade Students
}

\author{
Aybala Çayir \\ Department of Primary School Teaching, Faculty of Education, Aksaray University, Turkey
}

Copyright $\bigcirc 2017$ by authors, all rights reserved. Authors agree that this article remains permanently open access under the terms of the Creative Commons Attribution License 4.0 International License

\begin{abstract}
The purpose of this study was to analyze primary school first grade students' reading levels and correlate their visual perception skills. For this purpose, students' reading speed, reading comprehension and reading errors were determined using The Informal Reading Inventory. Students' visual perception levels were also analyzed using Beery-Buktenica Developmental Visual Motor Coordination Test. Results have shown that most of the students were in the anxiety (poor) level (75\%) and the rest of the children were in the instructional level (25\%). It has been found that instructional level first grade students had better scores in reading speed, reading comprehension, and reading errors. They also had significantly $(p<0.01)$ better scores on the visual perception test. The Pearson correlation test also indicated that there is a positive relation between visual perception skills (visual perception and visual motor coordination) and reading levels. It has been suggested that students' visual perception skills should be supported for successful reading processes.
\end{abstract}

Keywords Reading, Visual Perception, Reading Inventory, Primary School

\section{Introduction}

Providing adequate time for first grade students to read is one of the essential elements of a primary school program. The progression of fluent and meaningful reading begins after providing students basic reading and writing skills. Fluent and meaningful reading skills are related to students' progress in criticizing, discussion and thinking abilities. They can use their prior knowledge to acquire new meanings as well. It has been stated that students who don't develop age appropriate literacy skills by the end of third grade are at high risk of school failure [1].

Starting from early childhood education, reading skills of children are supported to improve their perception abilities [2]. Reading process of children includes visual perception, audio perception, memory, attention and language skills [3]. Deficiency in one of these skills will negatively affect reading. Visual information is transformed through a series of processing stages involving visual, phonological and episodic memory systems until it is finally comprehended in the semantic system [4]. Visual perception skills are directly related to differentiating written letters, words, and punctuation marks [5]. There are also spatial associations and figure-ground relations in visual perception affecting reading abilities. Therefore visual perception should be considered as a strong link to successful reading. They involve the ability to organize and interpret the information that is seen and give meaning to it. Many researchers support the importance of visual perception skills in academic success, state that reading would not be possible without adequate visual perception $[6,4]$.

It is evident that visual perception process has a leading effect on reading. Consequently, it is noticeable that inaccuracy in visual perception effects students' learning to read and reading comprehension processes. Because reading activities start in the first grade of primary school, it is important to examine first grade students' reading skills and visual perception level for their educational success.

\section{Method}

\subsection{Research Model}

One of the qualitative methods, relational scanning model, was used in this research. The measurements of primary school first grade students' reading skills and their perception levels were comparatively analyzed.

The population of the research was primary schools first grade students in Aksaray City. Aksaray is one of the urban cities of Turkey. The sampling was 80 students ( 40 girls and 40 boys) who attended three different primary schools from intermediate socio-economic status located in the main district. Purposive sampling method was chosen to determine the primary schools on a voluntary base. Students were 
randomly selected from four first grade classrooms.

\subsection{Data Collection Tools}

The Informal Reading Inventory was used in order to determine students' reading levels, reading comprehension, and reading errors. Beery-Buktenica Developmental Visual-Motor Coordination Test was used to determine their perception levels.

The Informal Reading Inventory was adapted to Turkish for Turkish students by Akyol [7]. This inventory was originally developed by Harris and Sipay [8], Shanker and Cockrum [9]. The purpose of the Informal Reading Inventory is to evaluate reader's individual reading level. This inventory helps to determine reading speed, reading error rates, vocabulary, and phonetics during oral reading. It also asks questions to determine reading comprehension after silent reading. There are three reading levels a student can achieve in the inventory. Independent level indicates that readers can read reading materials and comprehend them without adult help. For this level $99 \%$ word recognition and $90 \%$ comprehension is needed. Instructional level indicates that readers can read and comprehend with an adult help. This level comes between $90-99 \%$ word recognition and $51-89 \%$ reading comprehension. Anxiety (poor) level indicates that readers make mistakes that score below $90 \%$ for word recognition and below 50\% for reading comprehension. Two reading texts were selected from first grade level to measure reading errors and reading comprehension. These texts (Sleeping Beauty and Little Bear Vadu) were approved by the Ministry of Education for first graders. Two simple comprehension questions and three profound questions were formed related to each text. These two simple questions were used for recognition and memory, and three profound questions were used for inference and interpretation $[10,11]$.

Beery-Buktenika Developmental Visual Motor Coordination Test was developed by Beery and Beery [12]. This test has one main test for visual motor coordination and two additional tests for visual perception and motor coordination. Usage of additional tests is optional. This test was adapted to Turkish for Turkish children by Demirler [13]. It can be applied two years old children to 100 year-olds. For above five years old children, the test starts from page four test item seven. To be able to continue, the children have to correctly accomplish the item seven, eight and nine. Maximum score of 30 can be achieved using the main test and maximum score of 30 can be achieved using the visual perception test as well.

\subsection{Data Analysis}

Statistic Program for Social Sciences (SPSS, version 22.0) was used for analyzing data. Descriptive data was presented using frequency and percentage distributions. T-test was applied to analyze the differences between the reading levels (poor level and instructional level) of the children. There were not any children at the independent level in this study. Pearson Correlation Coefficient was applied to analyze the correlation between visual motor coordination and each reading skill (reading speed, reading comprehension and reading errors). For statistical analysis and interpretation, $p<0.01$ level was considered as significant.

\section{Findings}

This study examined the reading levels of the first grade students using the Informal Reading Inventory and Beery and Buktenika Developmental Visual Motor Coordination Test. The first table presents distribution of the students under three reading levels of Informal Reading Inventory.

Table 1. Reading levels of the first grade students

\begin{tabular}{|c|c|c|}
\hline Reading Levels & $f$ & $\%$ \\
\hline Anxiety (poor) level & 60 & 75 \\
\hline Instructional level & 20 & 25 \\
\hline Independent level & - & - \\
\hline Total & 80 & 100 \\
\hline
\end{tabular}

Table 1presentsthe reading levels of the primary school first grade students. It has been found that there were 60 students $(75 \%)$ in the anxiety (poor) reading level, and there were 20 students $(25 \%)$ in the instructional reading level. The study showed that there were not any students in the independent reading level. This finding is typical for the first grade students because they are still in the process of learning reading.

Table 2. Reading skills of the first grade students

\begin{tabular}{|c|c|c|c|c|c|}
\hline & & $N$ & $\bar{x}$ & $\mathbf{S}$ & $\mathbf{t}$ \\
\hline \multicolumn{6}{|l|}{ Reading Speed } \\
\hline Anxiety (poor) level & & 60 & 38.22 & 12.56 & \multirow{3}{*}{$-5.347 *$} \\
\hline \multirow[t]{2}{*}{ Instructional level } & & 20 & 55.52 & 14.12 & \\
\hline & Total & 80 & & & \\
\hline \multicolumn{6}{|c|}{ Reading Comprehension } \\
\hline Anxiety (poor) level & & 60 & 46.78 & 23.44 & \multirow{3}{*}{$-4.324^{*}$} \\
\hline \multirow[t]{2}{*}{ Instructional level } & & 20 & 81.56 & 12.55 & \\
\hline & Total & 80 & & & \\
\hline \multicolumn{6}{|l|}{ Reading Errors } \\
\hline Anxiety (poor) level & & 60 & 11.44 & 11.76 & \multirow{3}{*}{$7.542^{*}$} \\
\hline \multirow[t]{2}{*}{ Instructional level } & & 20 & 2.56 & 1.78 & \\
\hline & Total & 80 & & & \\
\hline
\end{tabular}

Table 2 presents the reading skills of the primary school first grade students. It has been found that the arithmetic mean score of the anxiety (poor) level students' reading speed was 38.22 and the arithmetic mean score of the instructional level students' reading speed was 55.52. Instructional level students had significantly $(-5.347)$ higher 
reading speed comparing to anxiety (poor) level students. It has also been found that reading comprehension of anxiety (poor) level students arithmetic mean score was 46.78 and reading comprehension of instructional level students arithmetic mean score was 81.56. Instructional level students had significantly (-4.324) higher reading comprehension comparing to anxiety (poor) level students. Besides, the study showed that reading errors of anxiety (poor) level students arithmetic mean score was 11.44 where reading errors of instructional level students arithmetic mean score was 2.56. Instructional level students had significantly (7.542) lower mistakes comparing to anxiety (poor) level students. These findings have proven that students with better reading abilities also had better scores in all sub-categories of reading skills.

Table 3. Reading levels and visual perception of the first grade students

\begin{tabular}{|c|c|c|c|c|}
\hline & $N$ & $\bar{x}$ & $S$ & $\mathbf{t}$ \\
\hline \multicolumn{5}{|l|}{ Visual perception } \\
\hline Anxiety (poor) level & 60 & 114.24 & 12.76 & \multirow{3}{*}{$-5.667 *$} \\
\hline \multirow[t]{2}{*}{ Instructional level } & 20 & 125.33 & 11.43 & \\
\hline & 80 & & & \\
\hline \multicolumn{5}{|l|}{ Visual motor coordination } \\
\hline Anxiety (poor) level & 60 & 113.43 & 15.86 & \multirow{3}{*}{$-5.122 *$} \\
\hline Instructional level & 20 & 123.53 & 12.55 & \\
\hline Total & 80 & & & \\
\hline
\end{tabular}

$p<0.01$

Table 3 presents the visual perception of the first grade students analyzing in terms of reading levels. It has been found that arithmetic mean was 114.24 for visual perception of anxiety (poor) level students and arithmetic mean was 125.33 for visual motor coordination of instruction level students. Instructional level students had significantly (-5.667) better visual perception comparing to anxiety (poor) level students. It has also been found that arithmetic mean was 113.43 for visual motor coordination of anxiety (poor) level students and arithmetic mean was 123.53 for visual motor coordination of instruction level students. Instructional level students had significantly $(-5.122)$ better visual motor coordination comparing to anxiety (poor) level students. These findings showed that instructional level students had better visual perception and visual motor coordination skills.

Table 4. Pearson correlation scores of reading skills and visual perceptions

\begin{tabular}{lccc}
\hline & $\begin{array}{c}\text { Reading } \\
\text { speed }\end{array}$ & $\begin{array}{c}\text { Reading } \\
\text { Comprehension }\end{array}$ & $\begin{array}{c}\text { Reading } \\
\text { Errors }\end{array}$ \\
$\begin{array}{l}\text { Visual perception } \\
\text { Visual motor }\end{array}$ & $.461^{*}$ & $.477^{*}$ & $-.412^{*}$ \\
coordination & $.454^{*}$ & $.465^{*}$ & $-.419^{*}$ \\
\hline$p<0.01$ & & &
\end{tabular}

Table 4 presents the Pearson correlation scores of reading skills (reading speed, reading comprehension and reading errors)and visual perceptions (visual perception and visual motor coordination). It has been found that there were significant correlation between visual perception and reading speed (.461), visual perception and reading comprehension (.477), and visual perception and reading errors (-.412). It has also been found that there were significant correlation between visual motor coordination and reading speed (.454), visual motor coordination and reading comprehension (.465), and visual motor coordination and reading errors (-.419).Results indicated that students with better visual perception and visual motor coordination skills had better reading speed and comprehension. Besides, they had lower reading errors.

\section{Discussion}

The purpose of this study was to examine the reading levels of the primary school first grade students using the Informal Reading Inventory. It has also been questioned whether there was a correlation between reading levels and visual perception. Beery and Buktenika Developmental Visual Motor Coordination Test was applied to analyze these first grade students' visual perception skills. Results revealed that most of the first grade students participated in the study was in the anxious (poor) level (75\%) and there has been significant $(p<0.01)$ correlation between reading level scores and visual perception.

The study showed that first grade students in the instructional reading level had better visual perception skills. It has been seen that students with better visual perception skills scored better in reading speed, reading comprehension and reading error. These results are also supported by other researchers. In their studies Thompson [14] and Delcamp [15] found a significant relation between visual perception and reading success. In their study Memiş and Ayvaz Sivri [16] used the same data collection tool (Informal Reading Inventory) to evaluate first graders' reading level. They applied Developmental Test of Visual Perception to analyze visual perceptions of children. Their results also suggested that there was a strong relation between reading levels and visual perception skills. The number of the children in the anxiety (poor) reading level were high (79\%) as well. In addition, Kavale and Forness [17] indicated that auditory and visual perception skills have a positive effect on reading achievement.

Based on these results, it can be concluded that visual perception skills are significant constituents to support students' reading skills. Teaching reading and reading comprehension is very important for children for their later success in school. To achieve this goal, students' visual perception skills need to be taken into consideration and they should be supported.

\section{REFERENCES}

[1] Snow, C. E. \& Matthews, T. J. (2016). Reading and Language in the Early Grades Reading and Language in the Early Grades. Future of Children, 26 (1), 57-74 
[2] Duman, G. (2015). Okul öncesi ĕgitimde beden eğitimi ve oyun ögretimi. Ankara: Eğiten Kitap Yayınları.

[3] Çayır, A. \& Balcı, E. (2017). Bireyselleştirilmiş okuma programının disleksi riski olan bir ilkokul öğrencisinin okuma becerileri üzerindeki etkisi. Uluslararası Türkçe Edebiyat Kültür Eğitim Dergisi, 6 (1), 455-470.

[4] LaBerge, D. \& Samuels, S. (1974). Toward a theory of automatic information processing in reading. Cognitive Psychology, 6 (2), 293-323.

[5] Duru, H. (2008). Gelişimsel görsel algl testi-2'nin 6 yaş çocukları için güvenirlik ve geçerlik önçalışması (Unpublished master's thesis). Marmara Üniversitesi, İstanbul, Turkey.

[6] McCandliss, B. D., Cohen, L. \&Dehaene, S. (2013). Thevisual word form area: expertise for reading in the fusiformgyrus. Trends in Cognitive Sciences, 7 (7), 293-299.

[7] Akyol, H. (2008). Yeni programa uygun türkçe öğretim yöntemleri. Ankara: Kök Yayıncılık

[8] Harris, A. J \&Sipay, E. R. (1990). How to Increase Reading Ability: A Guide to Developmental and Remedial Methods, 9 th Ed.

[9] Shanker, J. L. \&Cockrum, W. (2014). Ekwall/Shanker Reading Inventory, 6th Ed., Pearson.

[10] Akyol, H. (2013). Türkçe öğretim yöntemleri. Ankara: Pegem Akademi Yayınc1lık.
[11] Akyol, H. \&Kodan, H. (2016). Okuma güçlüğü olan bir öğrencinin okuma güçlüğünün giderilmesine yönelik bir uygulama: akıc1 okuma stratejilerinin kullanımı. 19 Mayıs̈̈niversitesi Ĕgitim Fakültesi Dergisi, 35 (2).

[12] Beery, E. \&Beery, N.(2010). Beeryvmı with suplemental developmental tests of visual perception and motor coordination administration, scoring and teaching manual. (6 th Ed.), Minneapolis: NCS Pearson.

[13] Demirler, F. (2016). 36-79 aylık çocuklar üzerinde uygulanan beery-buktenica gelișimsel görsel-motor koordinasyon testinin geçerlik ve güvenirlik çalışması. Yüksek Lisans Tezi, Okan Üniversitesi Sosyal Bilimler Enstitüsü, İstanbul.

[14] Thompson, L. J. J. (1975). The relationship of visual perception to reading achievement and the effects of two types of visual perceptual training on reading achievement in the first-grade year (Un published doctoral dissertation). University of Southern Mississippi.

[15] Delcamp, L. N. (1983). Relationships among conservation abilities, auditory and visual perception skills and school achievement of first grade students (Unpublished master's thesis). University Of Florida.

[16] Memiş, A., AyvazSivri, D. (2016). The Analysis of Reading Skills and Visual Perception Levels of First Grade Turkish Students. Journal of Education and Training Studies, V4, n8, RedfamePub.

[17] Kavale, K., \& Forness, S. (2000). Auditory and visual perception processes and reading ability: a quantitative reanalysis and historical interpretation. Learning Disability Quarterly, 23, 253-270. 